\title{
Second Kidney Transplant in a Patient with Artificial Urinary Sphincter
}

\section{Yapay Üriner Sfinkterli Hastada İkinci Böbrek Transplantasyonu}

\author{
Gavin Tansley, Sertaç Çimen, Sanem Güler Çimen, Mark Walsh \\ Dalhousie University, Multi Organ Transplant Program, Halifax, Canada
}

\begin{abstract}
Artificial urinary sphincter (AUS) is regarded as the gold standard treatment for post-prostatectomy urinary incontinence. Kidney transplantation is gold standard treatment for end stage renal disease. Since both AUS implantation and renal transplant surgeries are relatively common, a cooccurrence is likely and a patient with AUS may need a kidney transplant. Herein, we report a patient with an AUS who underwent second kidney transplantation. Since the iliac fossa ipsilateral to the AUS parts had to be preferred for the second kidney transplant, risks of AUS damage and infection were higher. This report illustrates the precautions taken to minimize these risks.
\end{abstract}

Key Words

Kidney, transplantation, artificial, sphincter

\section{ÖZET}

Yapay üriner sfinkter (YÜS) post-prostatektomi üriner inkontinans tedavisinde altın standart olarak kabul edilmektedir. Böbrek nakli de son dönem böbrek hastalığının altın standart tedavisidir. Hem YÜS implantasyonu hem de böbrek nakli operasyonları nispeten sık yapıldığından, bir arada olmaları muhtemeldir; YÜS'ü olan bir hasta böbrek nakline intiyaç duyabilir. Burada ikinci kez böbrek nakli yapılan YÜS'lü bir hasta sunulmaktadır. YÜS parçalarının bulunduğu iliak fossa ikinci böbrek nakli için tercih edilmek zorunda kalındığından, YÜS hasarı ve enfeksiyon riski yüksektir. Bu olgu sunumu bu riskleri azaltmak için alınacak önlemleri göstermektedir.

Anahtar Kelimeler

Böbrek, transplantasyon, yapay, sfinkter

\section{Introduction}

Artificial urinary sphincter (AUS) is a device that is used to treat urinary incontinence. It has 4 components: Reservoir that is implanted next to the urinary bladder, pump placed inside the scrotum, circular inflatable cuff that is placed around the urethral sphincter and the connectors (1). AUS was first introduced in 1973 and its popularity increased dramatically: In 2008, approximately 3000 AUS implants were performed in United States alone (2). Today, AUS is widely regarded as gold standard treatment for post-prostatectomy urinary incontinence.

Kidney transplant is regarded as gold standard treatment for end stage renal disease (ESRD) (3). The incidence of ESRD continued to rise during the last two decades and consequently it led to 14000 kidney transplants per year in United States (3). Repeat kidney transplants constituted $13 \%$ of the kidney transplants (3).

Since both AUS implant and kidney transplant surgeries are relatively common, a co-occurrence is likely; i.e. patients who have AUS may need kidney transplant or kidney retransplant. These patients need careful pre-operative management for avoidance of AUS-related complications.

Here, we report a 63-year-old male patient who underwent a kidney retransplant. He had AUS (AS 800TM) inserted prior to the first kidney transplant. The first kidney transplant and AUS complicated the second renal transplant surgery since iliac fossae were occupied by AUS reservoir and the failed allograft. In this case, we had to modify our surgical approach.

\section{Case Presentation}

A 63-year-old male patient was admitted for a cadaveric kidney transplant. His medical history was remarkable for chronic glomerulonephritis and a cadaveric kidney transplant which failed due to rejection. He was on hemodialysis.

Five years before his first kidney transplant, he underwent radical retropubic prostatectomy for prostate cancer. Subsequently, he developed urinary incontinence and required AUS (AS 800TM) implantation. Since the AUS reservoir was in the right iliac fossa, the first renal allograft was transplanted into the left iliac fossa. 
Physical examination revealed incision scars consistent with past surgical history. The renal allograft and the AUS pump were palpable in the left lower quadrant and right hemiscrotum respectively. A left brachiocephalic fistula was detected. Pre-transplant immunological investigations detected cumulative panel reactive antibody level of 67\%. He had 2 out of 6 human leukocyte antigen mismatches with his donor.

Antithymocyte globulin (125 mg, intravenous), methylprednisolone (500 mg, intravenous) and cefazolin (20 mg/kg, intravenous) were administered perioperatively as per our protocol. After induction of anesthesia, AUS was deactivated and urethral catheterization was performed using a 16F 3-way Foley catheter. This catheter was connected to a 1-Litre normal saline irrigation bag.

Right donor kidney was transplanted into right iliac fossa. Renal graft had a single vein and artery. A high Gibson incision was made to avoid the AUS parts. After dissection of the retroperitoneal space, we were able to feel the AUS reservoir and its connectors. In order to avoid the AUS, we deviated from our usual approach of using the external iliac vessels for anastomoses: We anastomosed the graft vein to inferior vena cava and the graft artery to right common iliac artery. Subsequently we filled the bladder with normal saline and placed a $16 \mathrm{~F}$ suprapubic catheter anteriorly. After re-inflating the bladder through the suprapubic catheter, we anastomosed the graft ureter to the right anterolateral wall of the bladder by Lich-Gregoir technique. We inserted a $6 F_{1}, 14-\mathrm{cm}$ double-J ureteral stent. The surgical field was irrigated with antibiotic solution before fascia closure. We removed the urethral catheter and then re-activated the AUS. The suprapubic catheter was held in place. There were no intra-operative complications.

Tacrolimus, mycophenolate mofetil and prednisone were prescribed for maintenance immunosuppression. Trimethoprim-sulfamethoxazole was started for prophylaxis against Pneumocystis Jiroveci pneumonia and urinary tract infection as per our protocol. Patient had immediate graft function. Suprapubic catheter was capped on postoperative day 6 for verification of the patency of AUS function. After verification, the suprapubic catheter was removed on postoperative day 7. Patient was maintained on trimethoprim-sulfamethoxazole as per protocol. Stitches were removed on postoperative day 21 and wound opened partially immediately afterwards. There were no signs of wound infection. Vacuum-assisted closure was applied. Wound healed completely in 3 weeks.

There were no other postoperative complications. Stent was removed by flexible cystoscopy 6 weeks after transplant. Antibiotic prophylaxis was discontinued after the completion of 9-month. Patient continued to have good graft function with the serum creatinine level of 140 $\mathrm{mmol} / \mathrm{L}$ and was still continent at 12-month follow-up.

\section{Discussion}

Implantation of AUS improved the quality of life in selected patient populations (2). This led to an increase in its popularity (2). In line with this fact, the possibility of coming across a kidney transplant candidate with AUS increased.
However, kidney transplantation in a patient with AUS bears its unique risks such as AUS damage, urethral damage and AUS infection. These risks are higher when the patient is the candidate of a kidney retransplantation.

To our knowledge, we described the first case of a kidney retransplantation in a patient with AUS. In this report, we presented the precautions taken to avoid the aforementioned risks in the setting of kidney retransplantation. They included making a high Gibson incision, selection of inferior vena cava and common iliac artery as recipient vessels, placement of a suprapubic tube for urinary drainage and irrigation of the surgical field with antibiotic solution.

Thomalla et al. (4) reported the first kidney transplant in a patient with an AUS. It was a primary kidney transplant; therefore these authors avoided the AUS parts simply by utilizing the contralateral side. In line with our approach, they inserted a suprapubic tube to avoid further urethral damage to the urethral segment which might already be eroded by the AUS cuff $(4,5)$.

Thomalla et al. $(4,6)$ also referred to their experience with transplantation in recipients with inflatable penile prostheses. In 2 out of 3 cases the infectious complications led to loss of penile prostheses. Furthermore, the prosthetic infection was contributory to the death of one patient (6). In conclusion, they highlighted the importance of taking precautions aimed at prevention of prosthetic damage and infection. Our approach was in line with these recommendations.

Informed Consent: Consent form was filled out by all participants, Concept: Sertaç Çimen, Mark Walsh, Design: Sertaç Çimen, Mark Walsh, Data Collection or Processing: Gavin Tansley, Sanem Güler Çimen, Analysis or Interpretation: Gavin Tansley, Sanem Güler Çimen, Literature Search: Gavin Tansley, Sertaç Çimen, Writing: Gavin Tansley, Sertaç Çimen, Peer-review: Externally peer-reviewed., Conflict of Interest: No conflict of interest was declared by the authors, Financial Disclosure: The authors declared that this study has received no financial support.

\section{References}

1. James $M H_{1}$ McCammon KA. Artificial urinary sphincter for postprostatectomy incontinence: a review. Int J Urol 2014;21:536-543.

2. Matsushita $K$, Chughtai BI, Maschino AC, Lee RK, Sandhu JS. International variation in artificial urinary sphincter use. Urology 2012;80:667-672.

3. Magee JC, Barr ML, Basadonna GP, Johnson MR, Mahadevan S, McBride MA, Schaubel DE, Leichtman AB. Repeat organ transplantation in the United States, 1996-2005. Am J Transplant 2007;7:1424-1433.

4. Thomalla JV, Mitchell ME, Leapman SB, Filo RS. Renal transplantation in a patient with an artificial urinary sphincter device. J Urol 1988;139:573574.

5. Montague DK. Artificial urinary sphincter: long-term results and patient satisfaction. Adv Urol 2012;2012:835290.

6. Thomalla JV, Thompson ST, Rowland RG, Mulcahy JJ. Infectious complications of penile prosthetic implants. J Urol 1987;138:65-67. 